\title{
ri/segno
}

\author{
Alfonso Ippolito \\ Martina Attenni \\ Federica Caporrella
}

Abstract

All'interno del vasto ambito del patrimonio costruito, la città è senza dubbio uno degli elementi più complessi. La sua mutevolezza ne determina l'importanza quale testimonianza storica e, al contempo, la difficoltà nella sua conservazione. Riconoscendo la propria ambivalenza tra il tangibile e l'intangibile, la ricerca vuole proporre un approccio metodologico finalizzato alla sua conservazione d'insieme, come unico organismo. La conservazione, intesa come vivificazione e divulgazione della memoria, implica la necessità di elaborare un metodo di comunicazione efficace. L'uomo viene messo in condizione di poter riacquisire la conoscenza di un assetto urbano scomparso, e di metterlo in relazione con quello esistente, successivamente consolidatosi. Necessariamente, la ricerca muove i primi passi nell'ampio tema della percezione umana dello spazio: capire cosa c'è alla base del processo cognitivo umano ha permesso di identificare nella percezione visiva la strada da intraprendere per raggiungere l'obiettivo prefissato. La metodologia seguita, partendo dalla ricostruzione documentaria dell'assetto scomparso, conduce a una sua scientifica ricostruzione, delineando il progetto ri/segno, che, integrando modalità di comunicazione differenti, rende fruibile una percezione totale del luogo, un'esperienza urbana (spaziale e temporale) a $360^{\circ}$.

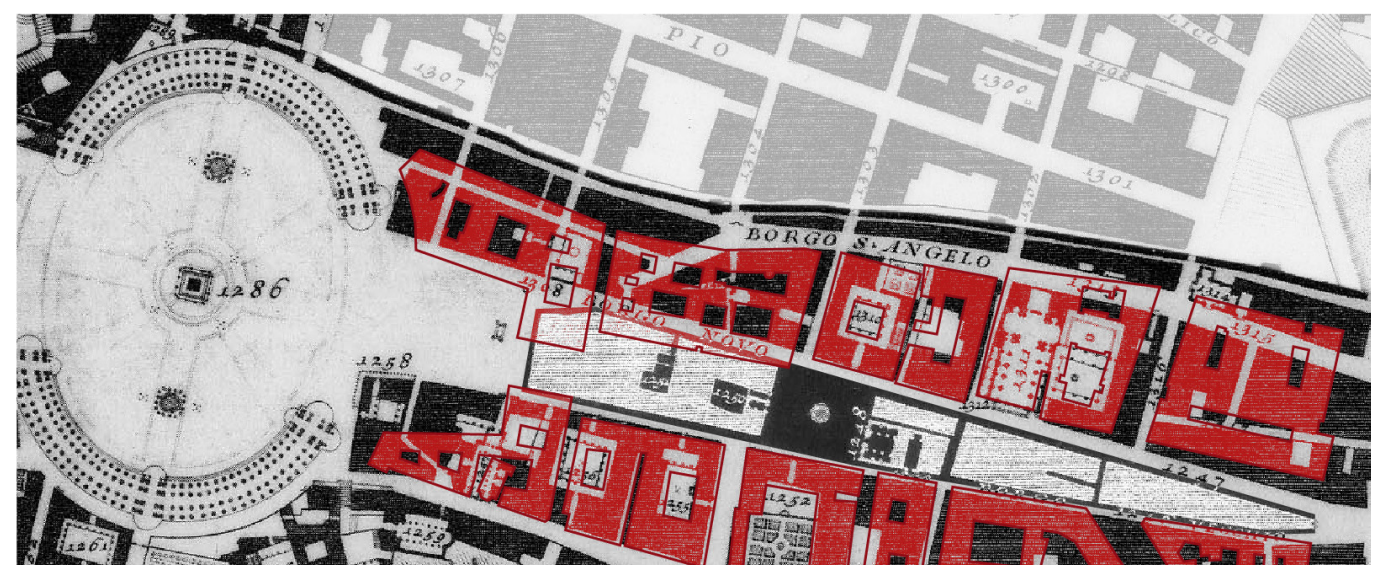


"La città non dice il suo passato, lo contiene come le linee d'una mano, scritto negli spigoli delle vie, nelle griglie delle finestre, negli scorrimano delle scale, nelle antenne dei parafulmini, nelle aste delle bandiere, ogni segmento rigato a sua volta di graffi, seghettature, intagli, svirgole"

[Italo Calvino 1972, p. 4]

Fig. I. Due fotografie storiche che mostrano il radicale cambiame durante gli sventramenti che hanno stravolto il tessuto romano negli tessuto romano negli an Spina di $X X$ secolo. La Spina di Borgo (a destra), completamente rasa suolo per l'apertura di via della Conciliazione ne 1937-38 (a sinistra). Fonte: archivio fotografico romasparita.eu.
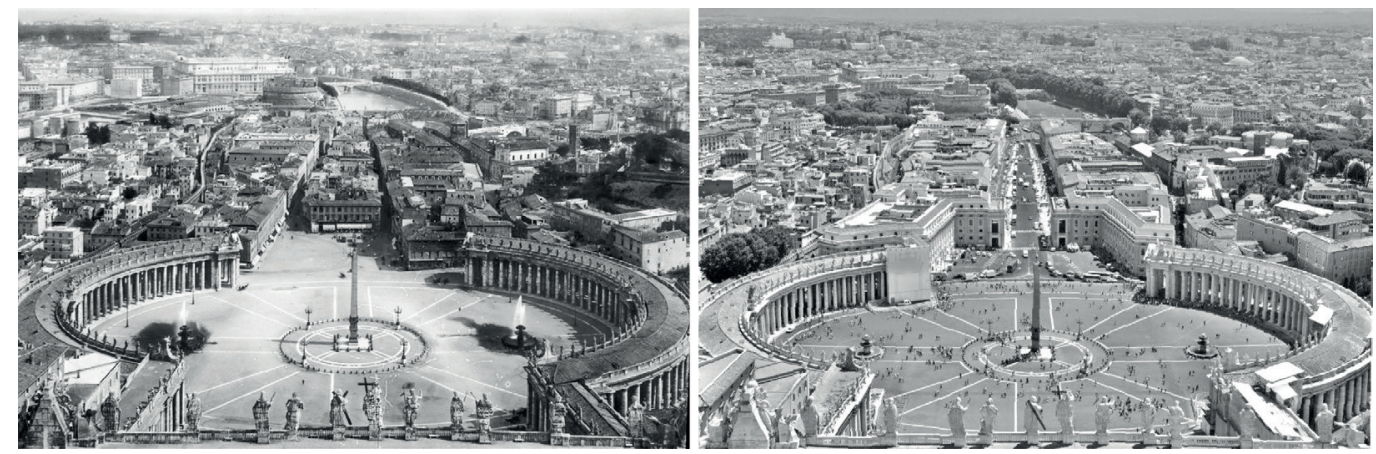

La ricerca si focalizza sulla conservazione e divulgazione di assetti urbani scomparsi, ai quali è riconosciuto il valore di patrimonio [2] intangibile. Quest'ultimo non vuole essere indagato nella sua autonomia; al contrario, l'obiettivo è quello di palesare le relazioni che instaura con l'esistente per ricostruire un tessuto urbano che possa essere letto nella sua interezza e che sia, di conseguenza, oggetto di condivisione totale. Si tratta quindi di stabilire la più efficace modalità attraverso cui raccontare spazi urbani esistenti e scomparsi, intesi come un unico nuovo sistema, e i rapporti che intercorrono tra questi e l'uomo, inteso come simbolo della collettività urbana. La conoscenza di tali spazi muove dalle modalità con cui l'essere umano prende coscienza degli spazi in cui vive. L'uomo, inserito all'interno di un sistema concreto di oggetti, subisce, dal contesto che lo circonda, una serie di sollecitazioni che generano in lui delle sensazioni; queste ultime altro non sono che l'ingenuo esito di un primitivo processo di conoscenza di cui l'uomo si ritrova a esserne il soggetto. Nel momento in cui queste informazioni vengono raccolte e "organizzate in oggetti, eventi o situazioni dotati di significato per il soggetto" [Vicario 1988] si può allora parlare di percezione, intesa come strumento di indagine e di conoscenza del mondo sensibile.

Conoscere uno spazio attraverso la sua percezione implica necessariamente che l'esperienza che l'uomo ha all'interno di quel contesto non si limiti a una raccolta di informazioni superficiali, ma presupponga un rapporto bidirezionale tra soggetto e oggetto; un processo attivo che parte dalla presa di coscienza dell'uomo stesso di essere inserito all'interno di un sistema con il quale ha la possibilità di interagire. Percepire uno spazio significa in questo senso 'relativizzarsi' a esso (fig. 2), prendere consapevolezza delle "nostre reazioni relativamente alla posizione del corpo nei confronti dell'ambiente" [Cullen 196I] [3].

L'uomo è quindi protagonista di un'esperienza urbana, soggetto di un processo di interazione che, nello specifico ambito di studio urbano, conduce al concretizzarsi nella sua mente 
di un"immagine ambientale' [4]. In questo senso, il ruolo di esplicitare le analisi condotte è demandato alla rappresentazione.

Si definisce quindi la ricerca di una modalità efficace attraverso cui raccontare percezioni spaziali, delineando l'immagine quale strumento attuativo. La percezione spaziale è intesa, quindi, come sintesi tra gli aspetti oggettivi e scientifici della costruzione geometrica di elementi urbani, e gli aspetti soggettivi, legati all'uomo e al suo essere organismo sensoriale, univocamente caratterizzato rispetto a qualsiasi altro suo simile per la propria sensibilità, conoscenza ed esperienza.

Due contributi si palesano nella definizione formale dell'immagine: da un lato, quelli provenienti dal mondo sensibile, la città come spazio reale esito della composizione di volume, materia e geometria; dall'altro, la sfera culturale, intellettiva, empirica che definisce le modalità attraverso cui l'uomo legge e interpreta i primi. L'immagine, esito di sintesi tra componenti reali (mondo sensibile) ed effimere (facoltà cognitive), costituisce il mezzo per comunicare, in maniera sempre più completa e attendibile, la percezione urbana.

Fig. 2. La scena urbana assume valori differenti in base alle modalità di relativizzazione Elaborazione rrafica basata su Cullen Gordon |96|. The Con cise Townscrope The Con(n)

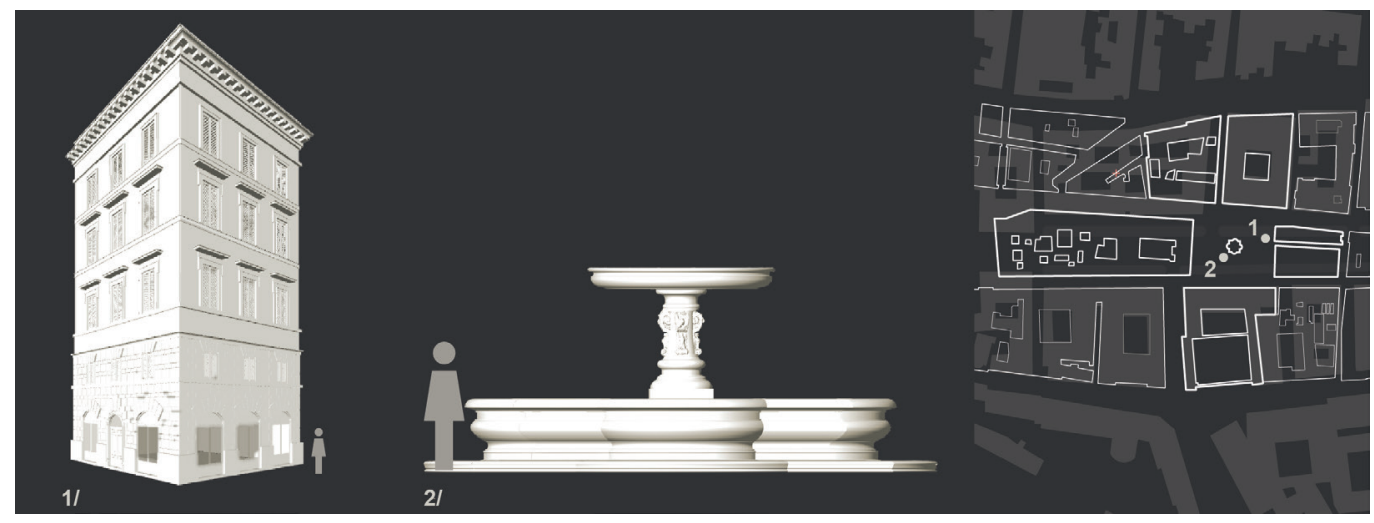

Bisogna a questo punto tracciare i contorni di quello che è l'oggetto su cui tale rappresentazione si focalizza: si era infatti accennato nelle iniziali battute al concetto di patrimonio intangibile e alla volontà di una sua conservazione. A priori, questo significa che al tessuto urbano viene riconosciuta una 'unità di monumento e ambiente' [5]. In altre parole, si rintraccia nel passato un certo valore storico e documentario e una qualità estetica e formale. Nello specifico, il contesto storico è quello della Spina di Borgo a Roma [6] (fig. 3). Oggi risulta però scomparso,'effimero', e al suo posto si è consolidata quella che è la nuova forma della città,'reale', frutto anch'essa di scelte e azioni che rappresentano una collettività storica, sicuramente più recente, ma con pari diritti di essere conservata e divulgata.

Appare quindi evidente che la ricerca debba necessariamente considerare entrambe le entità che entrano in gioco, quella effimera e quella reale, e pervenire a una loro immagine organica e unitaria. Traslando quanto avviene negli studi in ambito linguistico, l'immagine ambientale viene delineata, quale esito di un processo conoscitivo e di relazione dell'uomo all'interno di uno spazio, finalizzato a mostrare un sistema che lega, atemporalmente, due configurazioni urbane. L'immagine può quindi essere intesa come la rappresentazione 'sincronica' di uno degli eventuali scenari, al quale si perviene presupponendo una successione degli eventi storici 'diacronica' [7].

Diacronia/sincronia, effimero/reale non sono nient'altro che due facce della stessa medaglia: il tempo. Questa sua lettura ne mette in luce l'ambivalente essenza come insieme di processi dinamici in successione e come elemento permanente di carattere storico-testimoniale. Una volta resi noti, almeno sotto l'aspetto teorico, i rapporti che legano le due entità di effimero e reale e, stabilito che l'immagine diventa strumento attraverso cui la percezione spaziale, generata dal nuovo sistema 'effimeroreale', unitario e organico, viene conservata e 
Fig. 3. Confronto planimetrico dell'assetto urbano del Rione Borgo prima e dopo le demolizioni. A destra l'attuale figurazione urbana con evidenziato il progetto proposto da Spaccarelli e Piacentini; a sinistra viene riportato l'ingombro degli edifici demoliti, sovrapposti all situazione odierna. divulgata, appare evidente come quanto detto possa sintetizzarsi in un unico concetto base, principio esso stesso della rappresentazione: il segno.

II segno, in questo caso, viene inteso secondo una triplice accezione - genesi della rappresentazione, elemento primo dell'immagine, e strumento di comunicazione - che sintetizza le tre fasi metodologiche della ricerca. La prima fase vede la rappresentazione al centro del processo di conoscenza, affiancando disegni, documenti d'archivio e immagini storiche alle testimonianze ancora oggi visibili. L'immagine, elemento principale della seconda fase, consente la lettura critica e l'elaborazione del prodotto attraverso cui le due scene urbane vengono messe in relazione. In conclusione, la fase di comunicazione è volta alla definizione
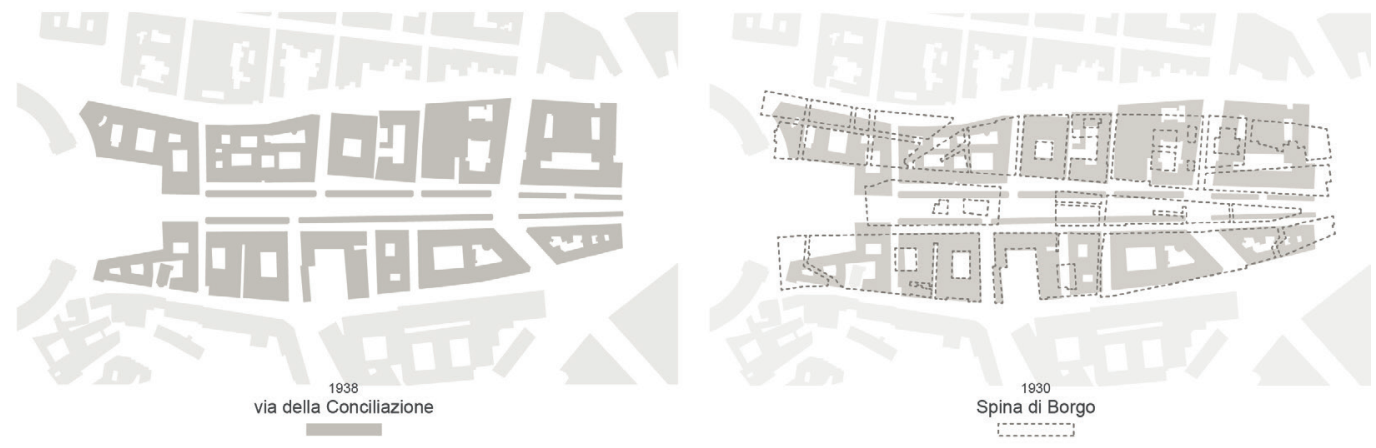

di modalità tramite cui quanto elaborato nelle fasi precedenti possa essere utilizzato ai fini divulgativi e conservativi.

Le diverse fasi raccontano l'assetto urbano, passato e presente, attraverso diverse declinazioni di un unico elemento: il segno (fig. 4). Inizialmente, il segno identifica l'ambito urbano di interesse. Esso, sebbene riconosciuto nella sua unità, rappresenta l'esito della composizione di un insieme di elementi, le unità architettoniche costituite dagli edifici. Queste architetture sono caratterizzate non solo dalle geometrie che definiscono i profili, ma anche da un altissimo valore storico, la cui gestione risulta piuttosto complessa. II processo di conoscenza ha previsto, da un lato, la raccolta e l'archiviazione di una grande quantità di dati eterogenei (documenti archivistici, fotografici, video, grafici, testuali). Dall'altro, ha reso possibile la lettura integrata finalizzata ad una congiunta e corretta interpretazione delle fonti, per la ricostruzione di una sequenza storica coerente e attendibile, complessa proprio perché ogni edificio - e ogni sua rappresentazione - è caratterizzato da un proprio linguaggio.

II materiale raccolto è stato classificato mettendo in relazione diversi criteri: lo stato di ciascun manufatto architettonico (demolito/esistente), la tipologia dato disponibile (ID/ 2D/3D), la sua collocazione (fondi archivi/musei/biblioteche), la modalità di acquisizione del dato (digitalizzazione di materiale cartaceo, ricostruzione virtuale di edifici non più esistenti, operazioni di rilevamento e costruzione di modelli degli edifici e degli ambiti urbani ancora esistenti) (fig. 5).

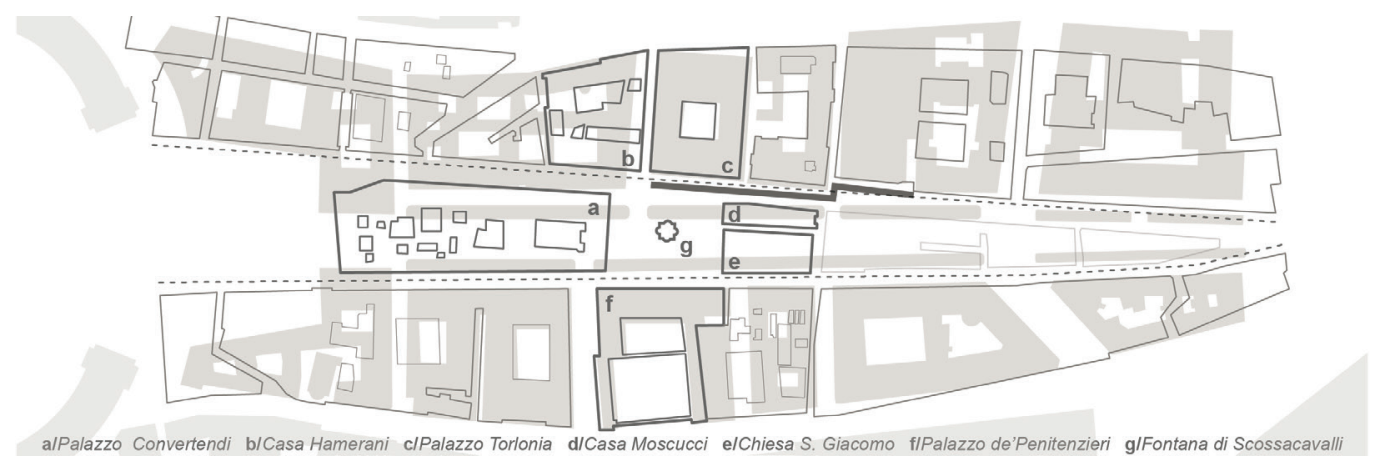

Fig. 4. Confronto tra i fronti perimetrali, che fino agli anni Trenta definivano i confini dell'ingombro della Spina, e gli odiern che costituiscono le quinte urbane di via della Conciliazione. Si osserva un'affinità tra i due tracciati: in corrispondenza della scomparsa piazza di Scossacavalli (e attualmente nell'area tra Palazzo Torlonia e Palazzo de' Penitenzieri) il tracciato antico si sovrappone a quello attuale. 
Fig. 5. Organizzazione e sistematizzazione de materiale eterogeneo raccolto nella prima fase della ricerca. Per ogni edificio sono state definite delle categorie secondo cui classificare dati.

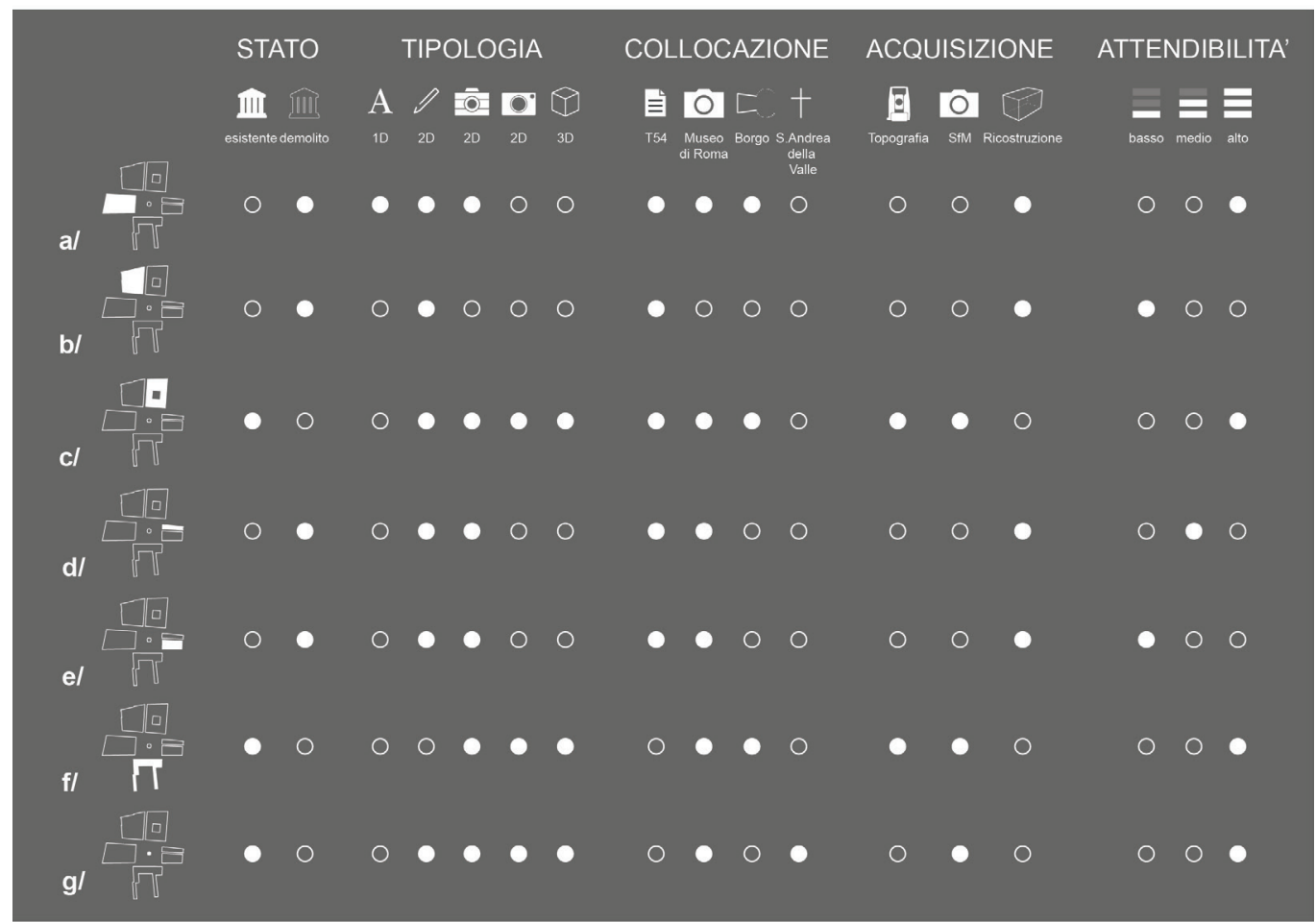

A questo punto, il segno diventa immagine, definita da un modello ricostruttivo. Contestualmente, la ricerca affronta la questione relativa alla scala del modello da adottare. Le informazioni quantitative e qualitative si concretizzano in modelli digitali che sono interpretazioni del mondo reale, scomposto in elementi notevoli [8].

Essi costituiscono, quindi, l'esito della conoscenza profonda e dell'interpretazione critica di un sistema urbano complesso e stratificato negli aspetti costruttivi e in quelli percettivi. In particolare, la volontà di suggerire contemporaneamente sia una percezione complessiva dello spazio, sia quella del fondale urbano costituito dagli edifici, caratterizzati da particolari aspetti architettonico-compositivi.

II modello si compone allora di due livelli: uno generale, che ricostruisce le spazialità, ormai effimere, degli edifici scomparsi, e uno di dettaglio designato alla ricomposizione stilistico-architettonica dei fronti (fig. 6).

Il segno muta allora per l'ultima volta, diventando comunicazione. La divulgazione del nuovo organismo 'effimeroreale', della nuova visione unitaria di patrimonio esistente e intangibile,

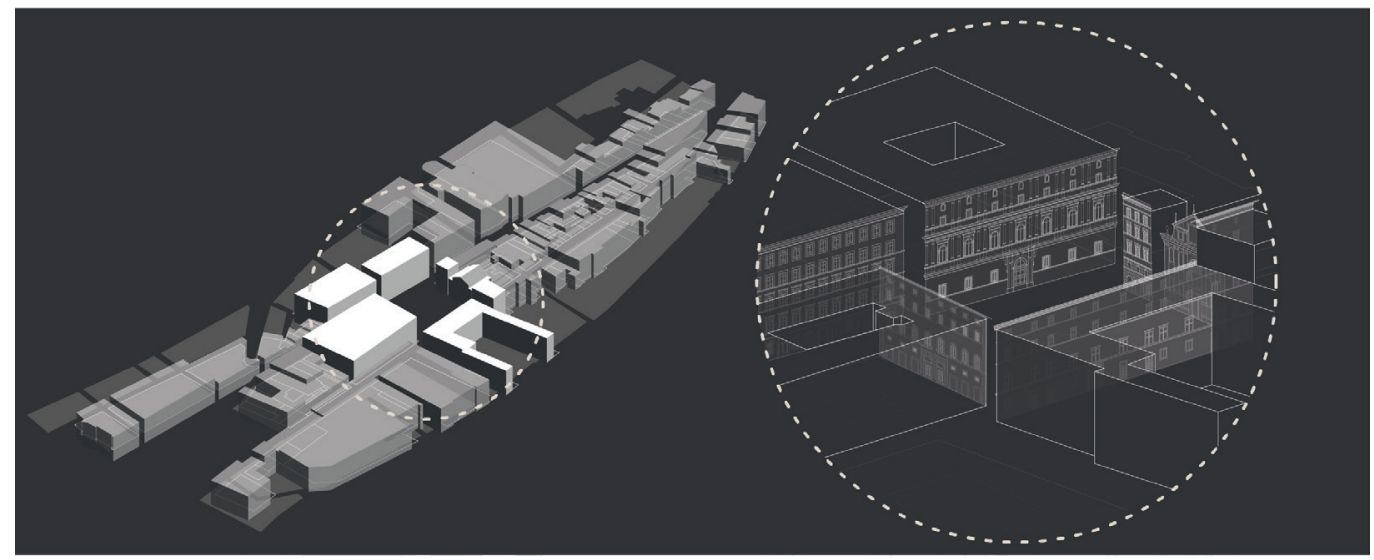

Fig. 6. La scala dei modelli costruiti in base alla finalità: definizione dello spazio urbano (a sinistra); espressione dei caratteri di ogni edificio che delimita l'invaso del piazza di Scossacavalli. 
Fig. 7. Viste sferiche elaborate dal modello virtuale, che permette di ricreare l'esperienza spaziale della piazza in tre precisi punti, scelti spe precisi punti, scelti in relazione al materia All'interno di piattaform di condivisione web le immagini sferiche diventano navigabili in modalità RV (Realtà irtuale) per mezzo di dispositivi mobili. permette di perseguire la loro unitaria conservazione. Le spazialità virtuali ricostruite si relazionano con quelle reali attraverso l'uso di tecnologie che, ormai alla portata di tutti, vengono definite innovative per le modalità attraverso cui sono utilizzate in tale contesto. Specificatamente, è la Realtà Virtuale (RV) che permette di immergere l'utente all'interno di un'esperienza conoscitiva aumentata, che viene designata quale strumento di comunicazione. Dal modello è infatti possibile estrapolare dei video sferici (fig. 7), successivamente caricati su una piattaforma di condivisione web (vista I https://youtu.be/75rJYX8NCVw; vista 2 https://youtu.be/_NkG_bGwxvY; vista 3 https://youtu.be/uhOBNfl6Gal) leggibile tramite il semplice utilizzo di smartphone e tablet. La stessa piattaforma permette poi di navigare nello spazio virtuale (effimero) muovendo il dispositivo come se si stesse inquadrando una scena da fotografare. II virtuale, ossia l'entità effimera, riacquista quindi una propria consistenza. Dal punto di vista teorico l'utilizzo sul posto concreto (reale) dell'esperienza virtuale (effimera), permette all'assetto urbano perduto di riappropriarsi del luogo, nel rispetto dell'esistente e del suo diritto di essere a sua volta tramandato.

Ri/segno è quindi punto di partenza, processo di elaborazione e metodo divulgativo per ri/ costruire l'effimero, ri/collegare l'effimero e il reale, ri/mostrare l'effimeroreale' come unico sistema (figg. 8, 9). Sintetizza un approccio metodologico che, partendo dal riconoscimento di un certo valore culturale [9], si snoda attraverso un processo di ricerca e analisi scientifica volto alla ricostruzione di sistemi di informazione attendibili e affidabili, destinati a essere divulgati alla comunità per conservare segni della sua storia e identità.
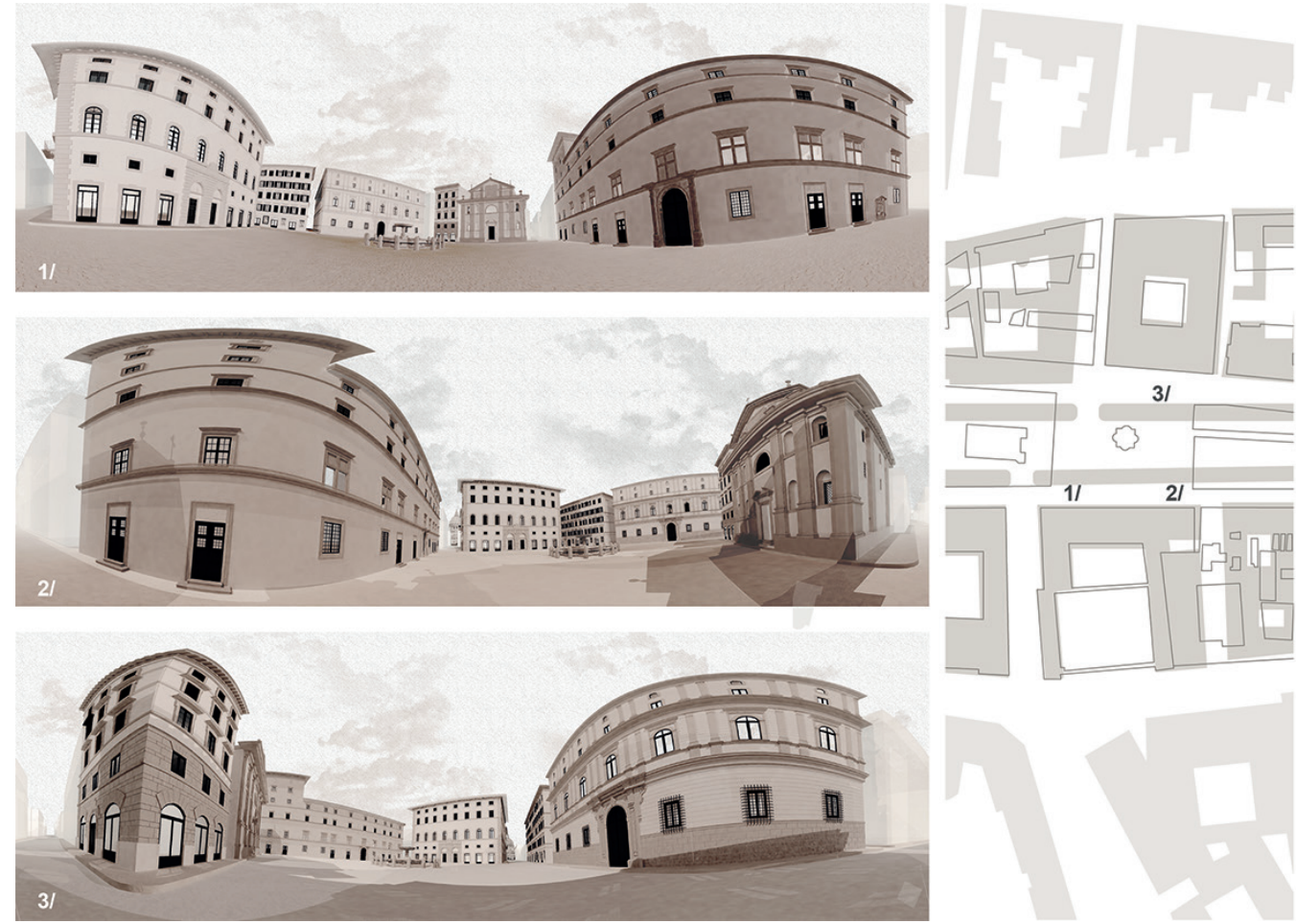

Note

[I] Rossi Aldo, 20 I 8. L'architettura della città. Edizione originale 1966. Milano p. 169.

[2] Nell'accezione di 'opera d'arte' teorizzata da Cesare Brandi caratterizzata da una "duplice polarità estetica e storica' [Brandi 1963].

[3] II metodo investigativo di Gordon Cullen parte dalla definizione di tre chiavi di lettura: ottica, luogo, contenuto. In particolare, per luogo viene inteso il rapporto corporale dell'uomo con gli elementi fisici che lo circondano (= posizione fisica rispetto all'ambiente e dimensionamento in relazione agli oggetti che lo compongono). 'lo sono fuori', 'sto entrando', 'sono al centro'; è un'istintiva e automatica abitudine fisica di relativizzarsi al contesto nel quale ci si trova. 

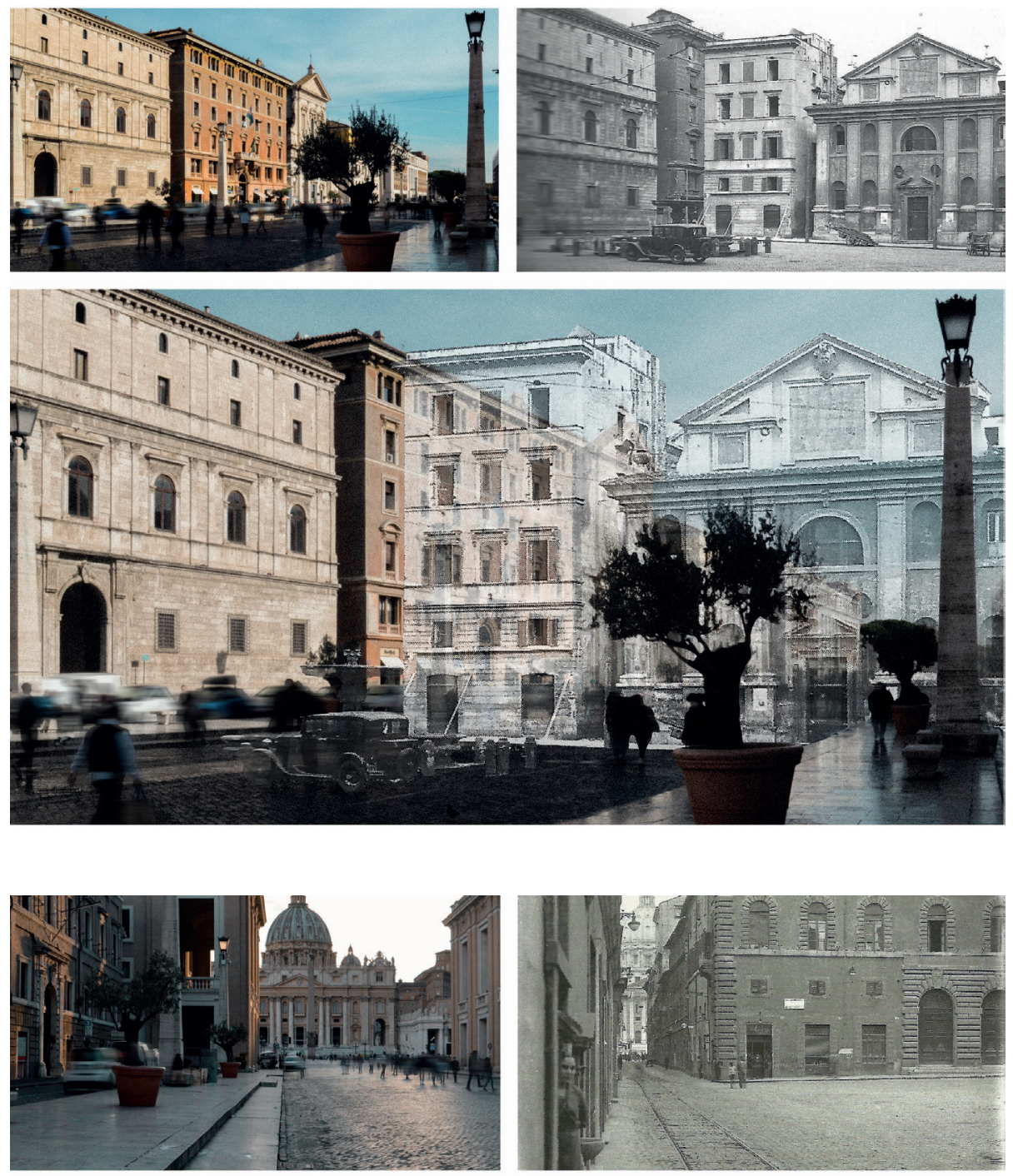

Figg. 8, 9. Confronto tra lo stato attuale (a sinistra)

e la situazione al 193

(a destra, Umberto Scia-

grafico sulla demolizion

della Spina di Borgo:

Archivio Storico Istituto

Luce). Le due immagini

sono messe in relazione

per rappresentare l'unita

'effimeroreale' ritrovata

(in basso).

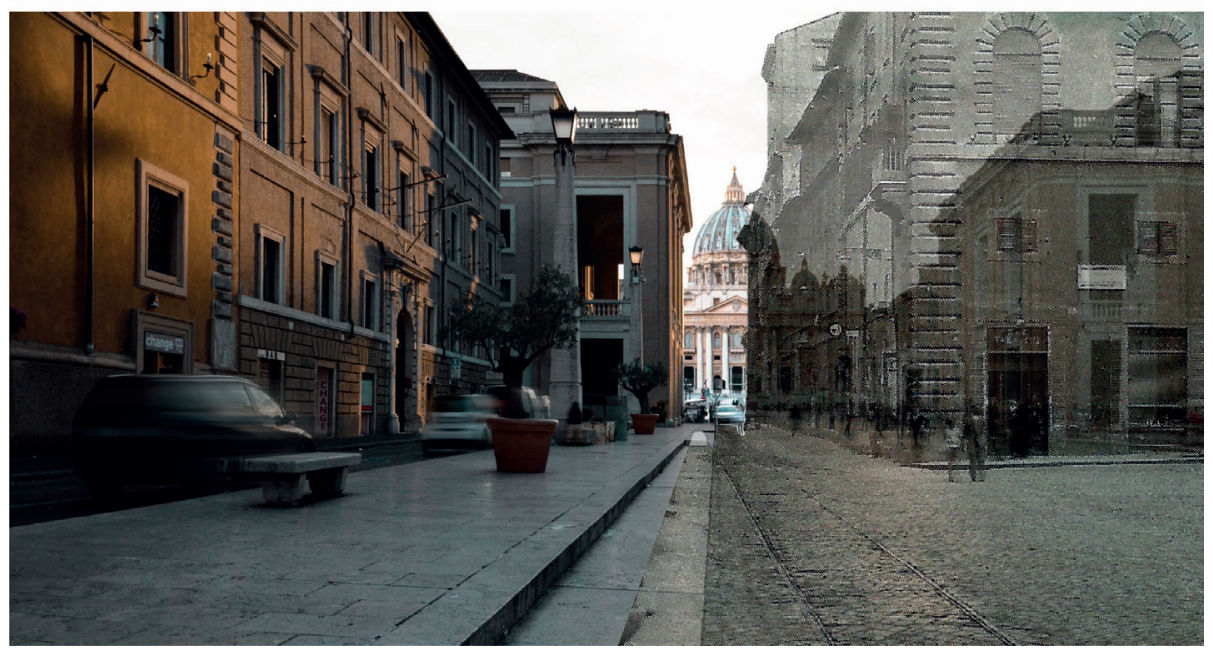


[4] Lynch Kevin 1960.

[5] Carbonara Giovanni, 1997. Avvicinamento al restauro. Teoria, storia, monumenti. Napoli: Liguori (spec. Capitolo terzo Unità di monumento e ambiente).

[6] L'applicazione pratica ha avuto come oggetto l'invaso urbano scomparso di piazza Scossacavalli. Questo, che si apriva al centro della Spina quale snodo di raccordo tra le due vie di Borgo Vecchio e Nuovo, rappresentava, e rappresenta tutt'ora nella memoria di chi ha potuto vivere quei posti, il simbolo di tutta la vita del quartiere. L'applicazione dell'approccio metodologico analizzato ha condotto in questo caso all'elaborazione di un progetto comunicativo che correva parallelamente su due fronti, pensati come un unicum ma utilizzabili anche singolarmente: da un lato la comunicazione virtuale offrendo esperienze di realtà immersiva, dall'altro la localizzazione di pannelli informativi in loco con il fine di 'educare all'osservazione' sfruttando la fotografia come strumento di connessione tra passato/presente, effimero/reale.

[7] I concetti di 'sincronico' e 'diacronico' vengono teorizzati in maniera compiuta dal linguista svizzero Ferdinand de Saussure, padre della linguistica moderna. Secondo la prospettiva 'sincronica', tutti gli aspetti di tale fenomeno che si verificano contemporaneamente in un determinato arco di tempo, vengono considerati come un sistema linguistico, regolato da precise leggi di funzionamento; in contrapposizione la linguistica diacronica considera le strutture e gli elementi linguistici nel loro succedersi e trasformarsi nel corso del tempo. Cfr. Ferdinand De Saussure. Cours de linguistique générale, 1916.

[8] Senatore Luca, La scala del modello digitale. In Bianchini Carlo, 20 I3, pp. I43-I 44.

[9] Brandi 1963.

\section{Riferimenti bibliografici}

Berger John (1972). Questione di sguardi. Sette inviti al vedere fra storia dell'arte e quotidianità. Milano: II Saggiatore.

Bianchini Carlo (20 I3). La documentazione dei teatri antichi del Mediterraneo. Le attività del del progetto Athéna a Merida. Roma: Gangemi Editore.

Brandi Cesare (1963). Teoria del restauro. Bologna: Einaudi.

Carbonara Giovanni (1976). La reintegrazione dell'immagine. Problemi di restauro dei monumenti. Roma: Bulzoni Editore.

Carbonara Giovanni (1997). Awicinamento al restauro. Teoria, storia, monumenti. Napoli: Liguori.

Cullen Gordon (1961). The Concise Townscrape. Oxford: Butterworth-Heinemann.

De Carlo Laura (2015). Metamorfosi dellimmagine urbana. Rappresentazione, documentazione, interpretazione, comunicazione. Roma: Gangemi Editore.

Lynch Kevin (1960). L'immagine della città. Venezia: Marsilio.

Sitte Camillo (I 889). L'arte di costruire la città. L'urbanistica secondo i suoi fondamenti artistici. Milano: Jaca Book, 2016.

Venturi Robert, Scott Brown Denise, Izenour Steven (1977). Learning from Las Vegas: The Forgotten Symbolism of Architectural Form. Cambridge (USA): MIT Press.

Zevi Bruno (1948). Saper vedere l'architettura. Roma: Einaudi (collana Piccola biblioteca Einaudi 2009).

Zevi Bruno, Benincasa Carmine (1986). Comunicare l'architettura. Torino: SEAT.

Autori

Alfonso Ippolito, Sapienza Università di Roma, alfonso.ippolito@uniromal.it

Martina Attenni, Sapienza Università di Roma, martina.attenni@uniroma L.it

Federica Caporrella, Sapienza Università di Roma, caporrellafederica@gmail.com

Per citare questo capitolo: Ippolito Alfonso, Attenni Martina, Caporrella Federica (2020). ri/segno/ri/segno. In Arena A., Arena M., Brandolino R.G., Colistra D., Ginex G., Mediati D., Nucifora S., Raffa P. (a cura di). Connettere. Un disegno per annodare e tessere. Atti del $42^{\circ}$ Convegno Internazionale dei Docenti delle Discipline della Rappresentazione/Connecting. Drawing for weaving relationships. Proceedings of the 42th International Conference of Representation Disciplines Teachers. Milano: FrancoAngeli, pp. 55।-566. 


\title{
rilsegno
}

\author{
Alfonso Ippolito \\ Martina Attenni \\ Federica Caporrella
}

\section{Abstract}

The city is undoubtedly one of the most complex elements of the vast built heritage. Its changes make it as an important historical testimony and, at the same time, implies the difficulty in its preservation. Recognising its ambivalence between the tangible and the intangible, the research aims to propose a methodological approach aimed at its overall conservation as a single organism. Conservation, understood as the revitalize and dissemination of the memory, implies the development of effective method of communication. The man regains the knowledge of a disappeared urban layout, and relate it to the existing one, later consolidated. The starting point of this research takes is the broad theme of human perception of space: understanding the basis of the human cognitive process has made it possible to identify in visual perception the key to achieve the set objective. The research methodology, starting from the documentary reconstruction of the disappeared structure, leads to its scientific reconstruction. The project, named ri/segno, integrates different modes of communication and allow to enjoy a total perception of the place, a $360^{\circ}$ urban experience (spatial and temporal).

Keywords

perception, communication, 3D/2D model, architectural heritage, tangible/intangible heritage.

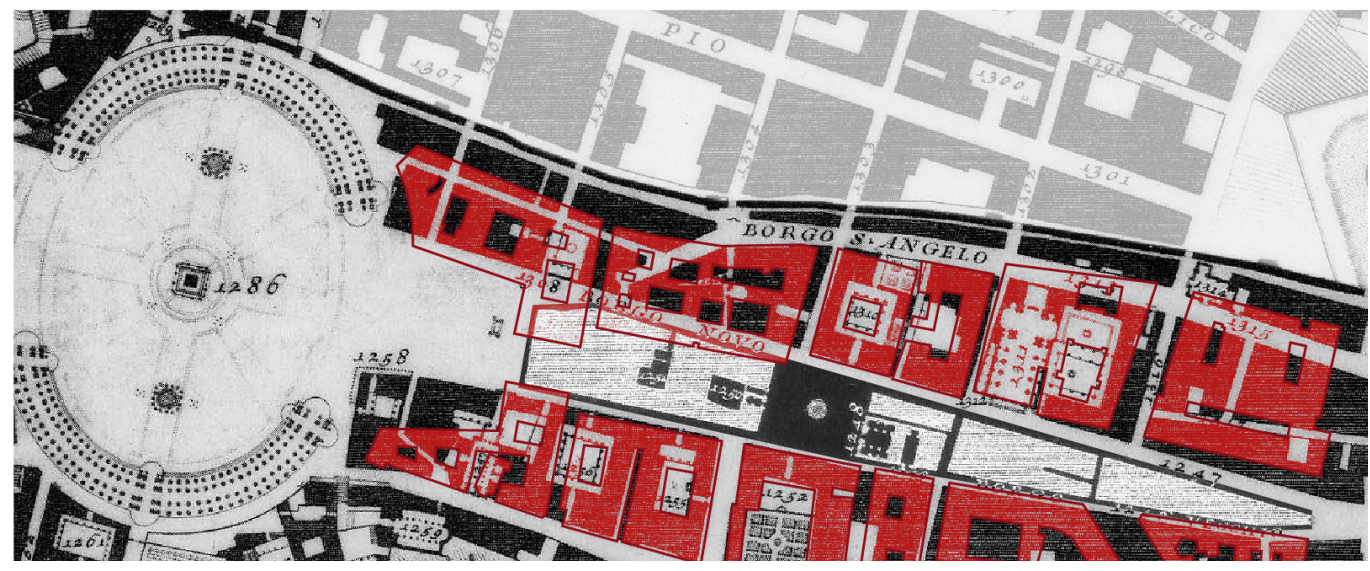


"The city does not tell its past, it contains it like the lines of a hand, written in the corners of the streets, in the grills of the windows, in the staircases, in the antennas of the lightning rods, in the flagpoles, each segment striped in turn of scratches, serrations, carvings'

[Italo Calvino 1972, p. 4].

Fig. I. Two historical photographs showing the radical change in the urban layout during the disembowelment that disrupted the Roman fabric in the 1930s. The Spina di Borgo (right), completely razed to the ground for the opening of Via della Conciliazione in 1937-38 (left). Source: photo archive romasparita.eu.
The city, as the set of 'urban facts' [Rossi 1966] among which man unfolds his experience, establishes with it a system of deep-rooted connections. These connections, due to their close interdependence, seems to become implicit many times (fig. I). In other words, the transformations of the space are the work of the community that inhabit and use those spaces. The city is therefore configured as the locus of collective memory [I] and has the right to be preserved and enhanced in the entirety of its complex system of transformations and stratifications.
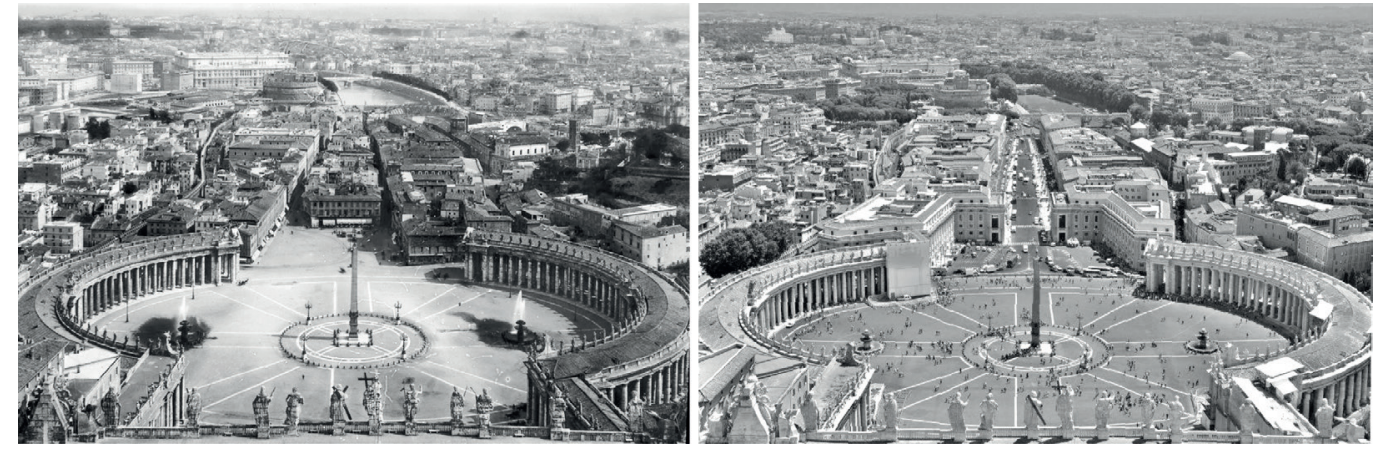

The research focuses on the conservation and dissemination of disappeared urban structures, to which the value of intangible heritage [2] is recognized. The research doen not investigate only the heritage. It's aim is to reveal the relationships it establishes with the existing one in order to rebuild an urban fabric that can be read in its entirety and that, consequently, is the object of total sharing. The core is to establish the most effective way to narrate existing and disappeared urban spaces, understood as a single new system, and the relationships between them and man, understood as a symbol of the urban community. The knowledge of these spaces moves from the ways in which human become aware of the spaces in which they live. The man who lives in a concrete system of objects, suffers, from this context, a lot of solicitations that generate in him different feelings.

The man is the subjet of a primitive process of knowledge about many heterogeneous information. When this information is collected and "organized into objects, events or situations with meaning for the subject" [Vicario 1988] we can then speak of perception as tool for understanding and knowledge of the sensitive world.

Knowing a space through its perception necessarily implies that the experience that man has within that context is not limited to a collection of superficial information, but presupposes a bidirectional relationship between subject and object. This is an active process that starts from man's awareness of being inserted within a system with which he has the possibility to interact. Perceiving a space means in this sense to "relativize oneself to it" (fig. 2), to become aware of "our reactions regarding the position of the body in relation to the environment" [3].

Man is therefore the protagonist of an urban experience, subject of an interaction process which, in the specific field of urban study, leads to the concretization in his mind of an environmental image [4]. In this sense, the role of explicit the analyses conducted is entrusted to representation. 
This research therefore tries to define an effective way to narrate the spatial perception, outlining the image as an implementation tool. Spatial perception is here understood as a synthesis between the objective and scientific aspects of the geometrical construction of urban elements, and the subjective aspects. These aspects are linked to man and his being a sensory organism, univocally characterized by its sensitivity, knowledge and experience. Two contributions are evident in the formal definition of the image: those coming from the sensitive world -the city as the real result of the composition of volume, matter and geometry- and the cultural, intellectual, empirical sphere that defines the ways in which man reads and interprets the former. The image, the result of synthesis between real (sensitive world) and ephemeral (cognitive faculties) components, constitutes the means to communicate urban perception in an increasingly complete and reliable way.

Then, it is necessary to trace the contours of what is the object on which this representation focuses: the intangible heritage and the desire for its preservation. A priori, this means that the urban fabric is recognized as a unity of 'monument and environment' [5].

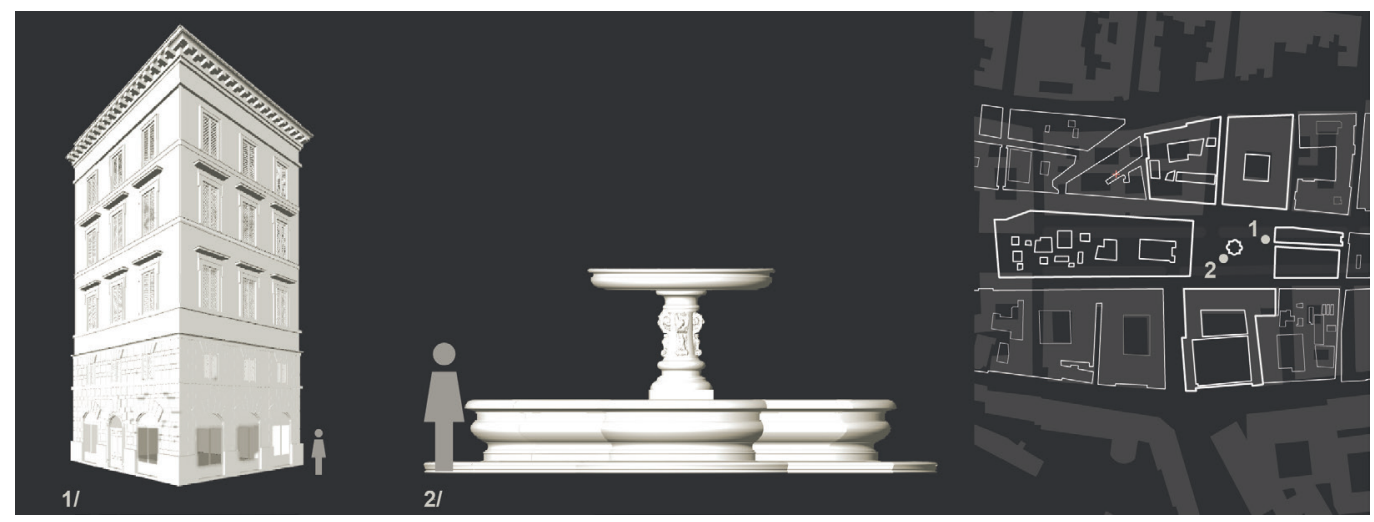

In other words, a certain historical and documentary value and an aesthetic and formal quality are found in the past.

Specifically, the historical context is that of the Spina di Borgo in Rome [6] (fig. 3). Today, however, it has disappeared, 'ephemeral', and in its place has been consolidated the new form of the city. The real city is also the result of choices and actions that represent a historical community, certainly more recent, but with equal rights to be preserved and divulged.

Therefore, the research must necessarily consider both entities, the ephemeral and the real, and arrive at an organic and unified image of them. Translating some studies in the linguistic field, the environmental image is outlined as the result of a process of knowledge and relationship of man within a space, aimed at showing a system that links, timelessly, two urban configurations. The image can therefore be understood as the synchronic representation of one of the possible scenarios, which is achieved by assuming a succession of diachronic historical events [7].

Diachrony/synchrony, ephemeral/real are nothing more than two sides of the same coin: the time. This reading highlights its ambivalent essence as a set of dynamic processes in succession and as a permanent element of historical-testimonial character.

The relationships that link the two entities of ephemeral and real have been made known. At least from a theoretical point of view, the image becomes an instrument through which spatial perception, generated by the new ephemeral, unitary and organic system, is preserved and divulged. This concept can be summarized in a single basic concept, the very principle of representation: the sign. 
Fig. 3. Planimetric comparison of the urban layout of the Borgo district before the On the right the current On the right the current urban figuration with the project proposed by Spaccarelli and Piacentin highlighted; on the left the overall dimensions of the demolished buildings, superimposed on the current situation.
The sign, in this case, is understood according to a triple meaning - genesis of representation, first element of the image, and communication tool- which synthesizes the three methodological phases of the research. In the first phase the representation is the centre of the knowledge process, flanking drawings, archival documents and historical images to the evidence still visible today. The image, the main element of the second phase, allows a critical reading and elaboration of the product through which the two urban scenes are related. In conclusive phase, the communication, is aimed at defining ways in which what was elaborated in the previous phases can be used for divulgation and conservation purposes.
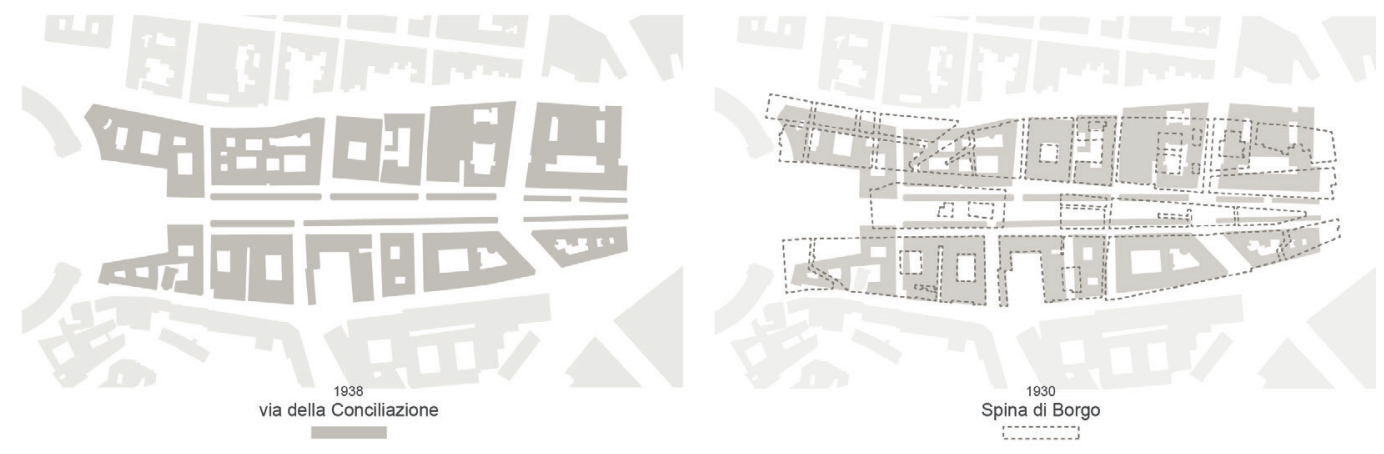

The different phases recount the urban layout, past and present, through different meanings of just an element: the sign (fig. 4). Initially, the sign identifies the urban context of interest. It, although recognized in its unity, represents the result of the composition of a set of elements, the architectural units constituted by buildings. These architectures are characterized not only by the geometries that define their profiles, but also by a very high historical value, whose management is quite complex. The knowledge process has involved the collection and archiving of a large amount of heterogeneous data (archival, photographic, video, graphic, textual documents). Furthermore, it has allows an integrated reading that aimed to a joint and correct interpretation of the sources, for the reconstruction of a coherent and reliable historical sequence, complex because every building - and every representation of it - is characterized by its own language.

The material collected has been classified by relating different criteria: the state of each architectural artefact (demolished/existing), the type of data available (ID/2D/3D), its location (archives/museums/libraries), the mode of data acquisition (digitisation of paper material, virtual reconstruction of buildings no longer existing, survey operations and construction of models of buildings and urban areas still existing) (fig. 5).

Then, the sign becomes an image, defined by a reconstructive model.

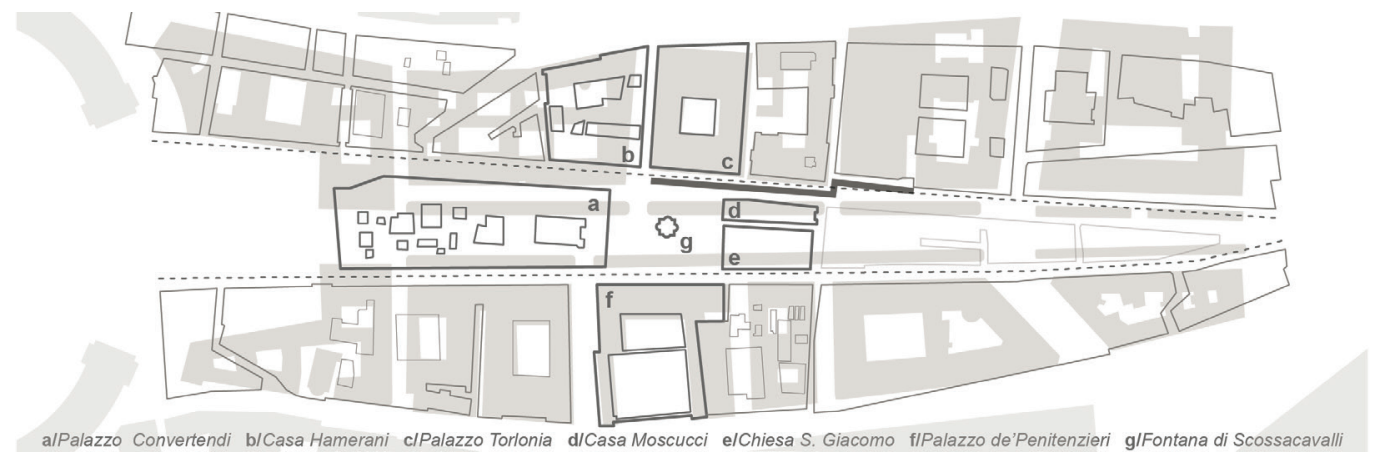

Fig. 4. Comparison between the perimeter fronts, which until the 1930 s defined the boundaries of the Spina's encumbrance, and today's urban backdrops of Via della Conciliazione. There is an affinity between the two tracks: in correspondence with the disappearance of Piazza di Scossacavali (and currently in the area between Palazzo Torlonia and Palazzo Penitenzieri) the ancient Penitenzieri) the ancient layout over laps wi 
Fig. 5. Organization and systematization of the heterogeneous materia collected in the first phase of the research. Categories have been defined for each building to classify the data.

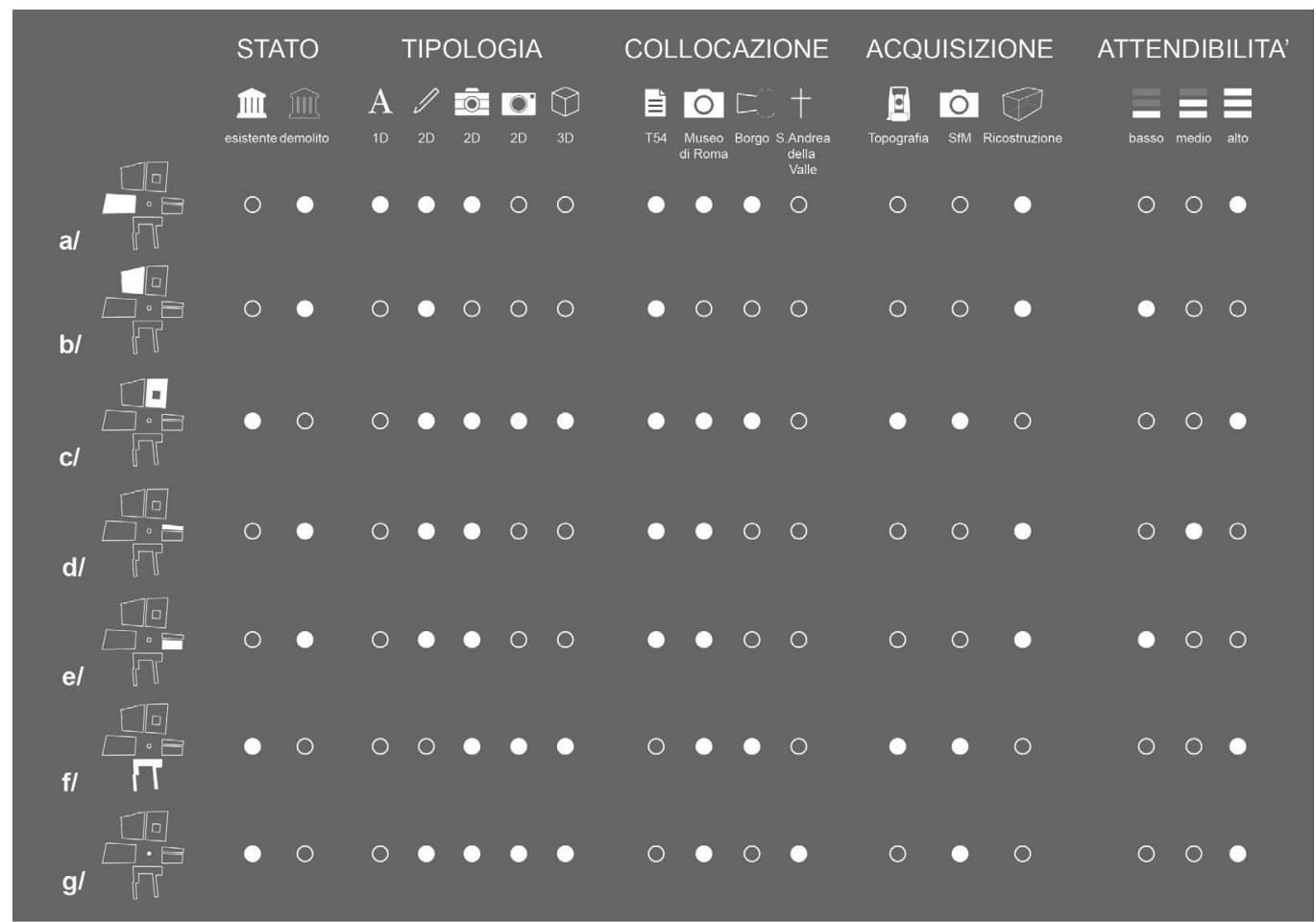

At the same time, the research addresses the question of the scale of the model to adopt. The quantitative and qualitative information are summarized in digital models that are interpretations of the real world, broken down into remarkable elements [8].

They constitute, therefore, the outcome of a deep knowledge and critical interpretation of a complex urban system stratified in its constructive and perceptual aspects. In particular, the desire to suggest both an overall perception of space and that of the urban backdrop made up of buildings, characterized by particular architectural-compositional aspects.

The model then consists of two levels: a general one, which reconstructs the now ephemeral spatiality of the disappeared buildings, and a detailed one designated to the stylistic-architectural recomposition of the fronts (fig. 6).

The sign then changes for the last time, becoming communication. The diffusion of the new ephemeral organism, of the new unitary vision of existing and intangible heritage, allows to pursue their unitary conservation. The reconstructed virtual spatialities are re-

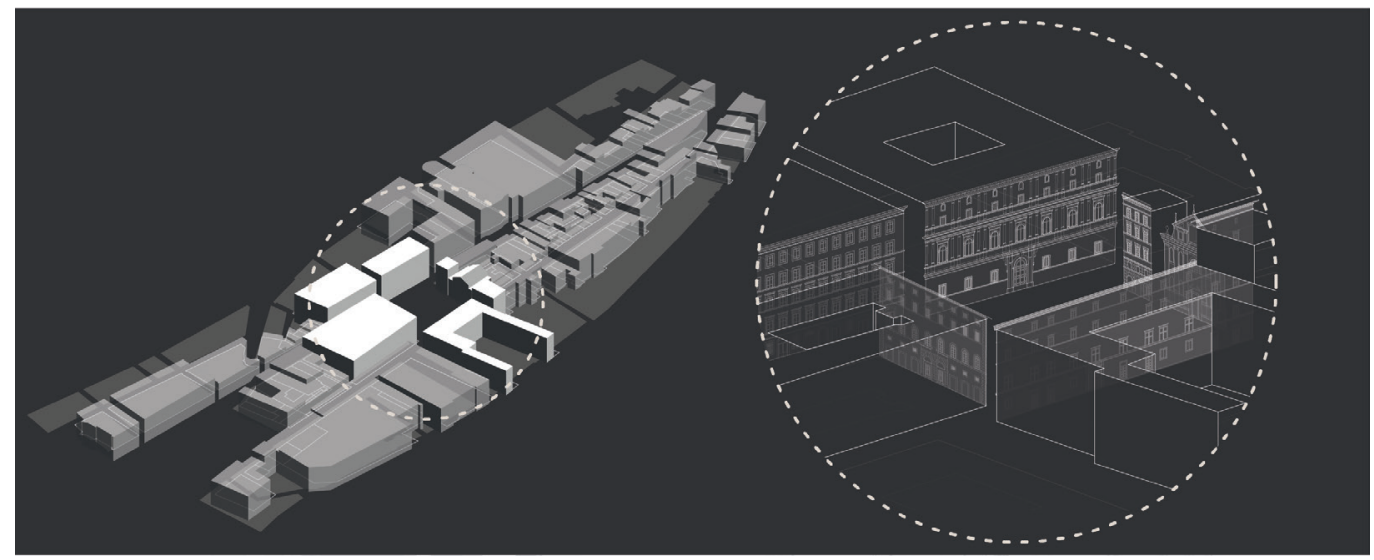


Fig. 7. Spherical views elaborated by the virtual model, which allows to recreate the spatial experience of the square in three precise points, chosen in relation to the historical materia collected. Within web sharing platforms the spherical images become navigable in RV (Virtual Reality) mode by means of mobile devices. lated to the real ones through the use of technologies. These technologies, now within everyone's reach, are innovative for the way they are used in this context. Specifically, the Virtual Reality (VR) as a communication tool, allows to immerse the user in an augmented cognitive experience. From the model it is in fact possible to see spherical videos (7), then uploaded on a web sharing platform (view I https://youtu.be/75r]YX8NCVw ; view 2 https://youtu.be/_NkG_bGwXvY; view 3 https://youtu.be/uhOBNfL6Gal) readable through the simple use of smartphones and tablets. The same platform then allows to navigate the virtual space (ephemeral) by moving the device as if you were framing a scene to be photographed. The virtual, that is the ephemeral entity, then regains its own consistency. From the theoretical point of view the use on the concrete (real) place of the virtual (ephemeral) experience, allows the lost urban order to regain possession of the place, respecting the existing and its right to be in turn handed down.

$\mathrm{Ri} /$ segno is therefore the starting point, process of elaboration and divulgation method to re/construct the ephemeral, re/connect the ephemeral and the real, re/show the ephemeral as the only system (figs. 8,9). It synthesizes a methodological approach that, starting from the recognition of a certain cultural value [9], unwinds through a process of research and scientific analysis aimed at the reconstruction of reliable information systems, intended to be disseminated to the community to preserve signs of its history and identity.
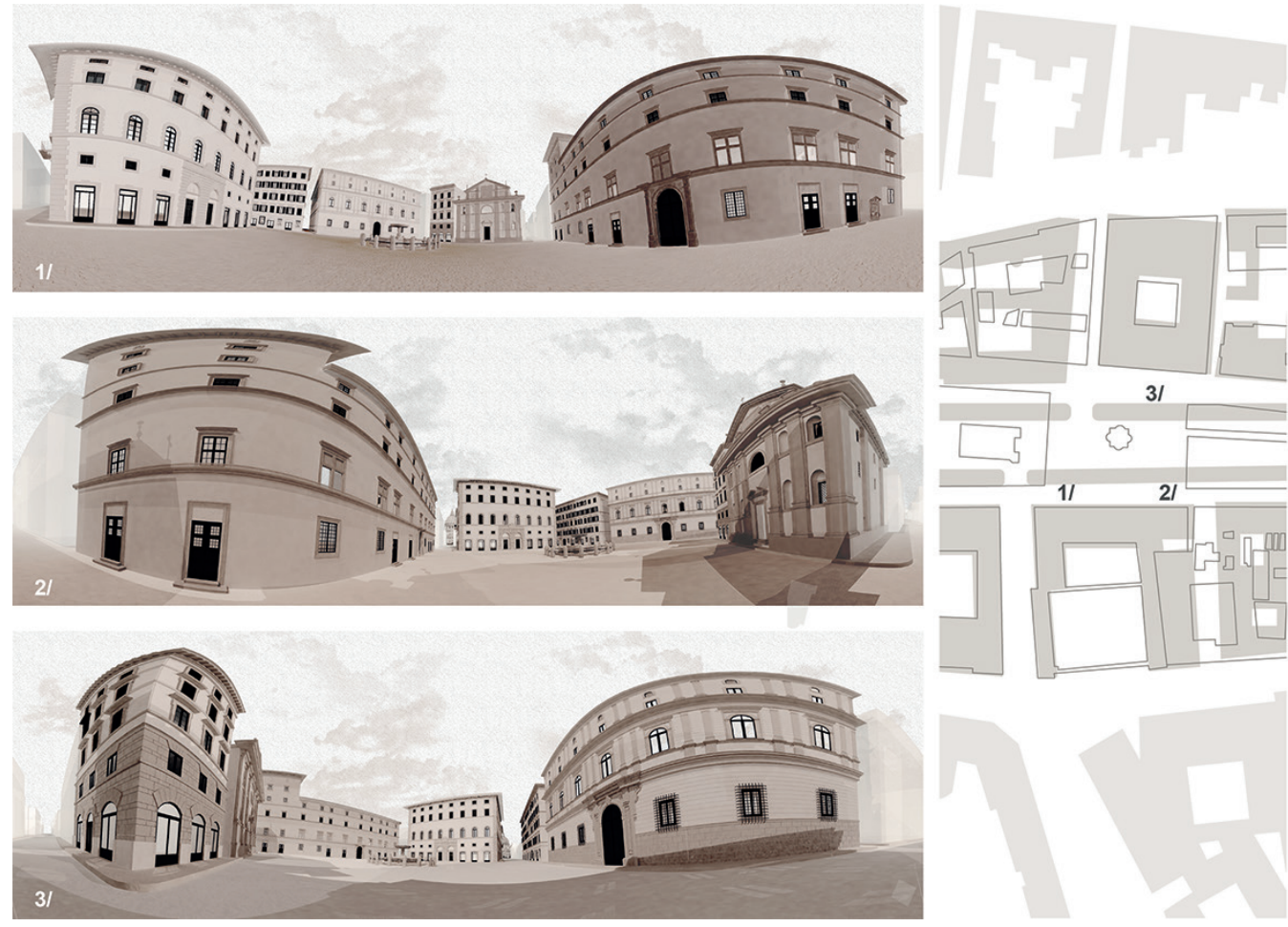

\section{Notes}

[I] Rossi Aldo, 2018. The architecture of the city. Milan. Ed. or. 1966, p. 169

[2] Intangible heritage is here understood in the sense of a work of art theorized by Cesare Brandi, characterized by a "dual aesthetic and historical polarity" (Brandi 1963).

[3] Gordon Cullen's investigative method starts from the definition of three keys of interpretation: optics, place, content. In particular, place is understood as the bodily relationship of man with the physical elements that surround him (= physical position with respect to the environment and dimensioning in relation to the objects that compose it). 'I am outside', 'I am entering','I am in the centre'; it is an instinctive and automatic physical habit of relativizing oneself to the context in which one finds oneself. 

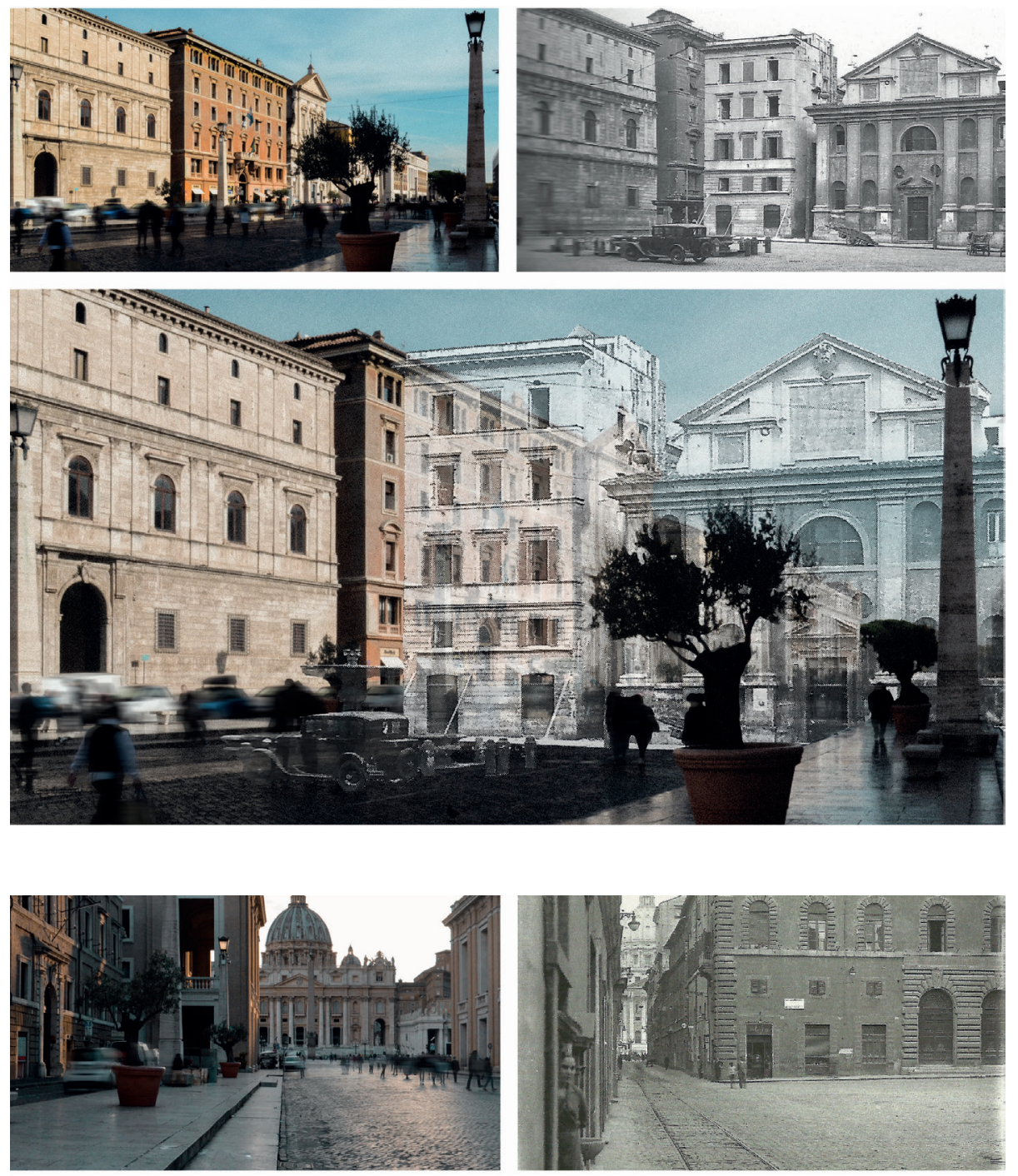

Figs. 8, 9. Comparison between the current state (left) and the situation at 1937 (right. Umberto Sciamanna, 1937, photographic report on the demolition of the the demolition of the
Spina di Borgo; Archivio Spina di Borgo; Archivio

Fotografico - Archivio
Storico Istituto Luce). The two images are related to represent the ephemera unity found (below)

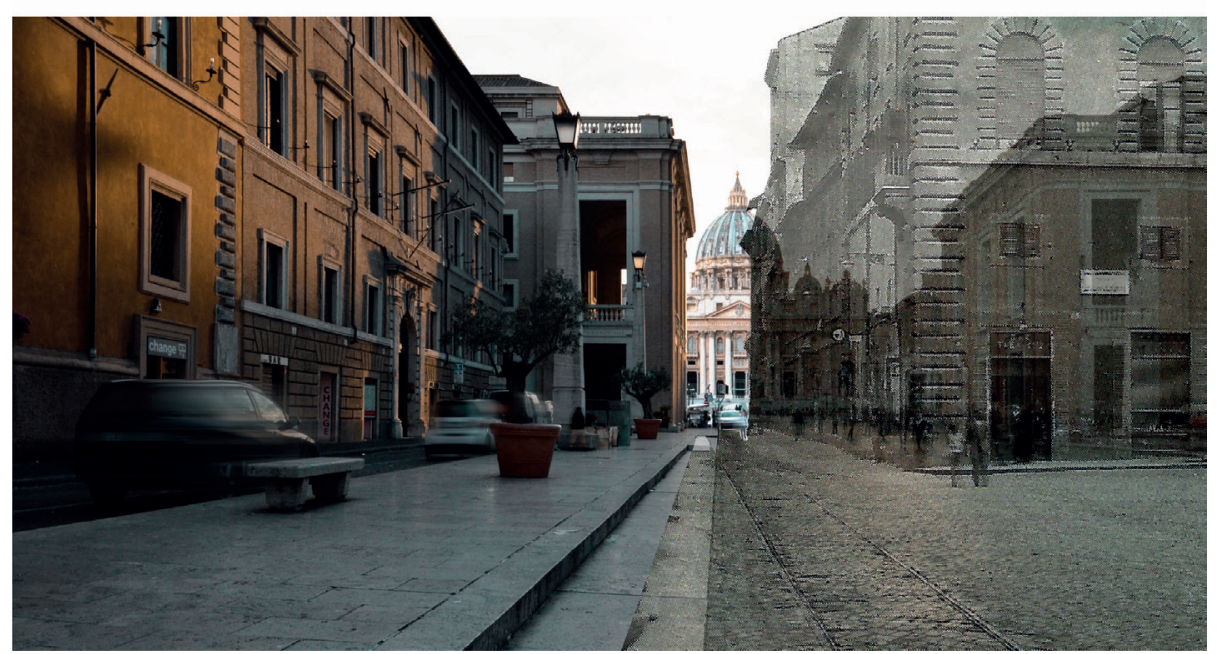


[4] Lynch Kevin, 1960.

[5] For more detailed studies: Carbonara Giovanni, 1997. Avvicinamento al restauro. Teoria, storia, monumenti. Naples: Liguori (ChapterThree Unità di monumento e ambiente).

[6] The practical application has had as object the disappeared urban invasion of Piazza Scossacavalli, wich opened at the centre of the Spina as a junction between the two streets of Borgo Vecchio and Nuovo. It represented, and still represents in the memory of those who were able to live those places, the symbol of all the life of the district. The application of the methodological approach analysed led in this case to the elaboration of a communicative project with different aims. The virtual communication offering experiences of immersive reality but also the localization of information panels on site with the aim of educating to observation, exploiting photography as a connection tool between past/present, ephemeral/real.

[7] The concepts of synchronic and diachronic are theorized by the Swiss linguist Ferdinand de Saussure, the father of modern linguistics. According to the synchronic perspective, all aspects of this phenomenon, which occur simultaneously in a given period of time, are considered as a linguistic system, regulated by precise laws of functioning; in contrast, diachronic linguistics considers the linguistic structures and elements as they succeed and transform over time. For more detailed studies: Ferdinand De Saussure, 1916. Cours de linguistique générale.

[8] For more detailed studies: Senatore Luca, The scale of the digital model. In Bianchini 20 I3, pp. I43-I 44.

[9] Brandi 1963.

\section{References}

Berger John (1972). Questione di sguardi. Sette inviti al vedere fra storia dell'arte e quotidianità. Milano: Il Saggiatore.

Bianchini Carlo (20 3). La documentazione dei teatri antichi del Mediterraneo. Le attività del del progetto Athéna a Merida. Roma: Gangemi Editore.

Brandi Cesare (1963). Teoria del restauro. Bologna: Einaudi.

Carbonara Giovanni (1976). La reintegrazione dell'immagine. Problemi di restauro dei monumenti. Roma: Bulzoni Editore.

Carbonara Giovanni (1997). Awicinamento al restauro. Teoria, storia, monumenti. Napoli: Liguori.

Cullen Gordon (1961). The Concise Townscrape. Oxford: Butterworth-Heinemann.

De Carlo Laura (2015). Metamorfosi dell'immagine urbana. Rappresentazione, documentazione, interpretazione, comunicazione. Roma: Gangemi Editore.

Lynch Kevin (1960). L'immagine della città.Venezia: Marsilio.

Sitte Camillo (I 889). L'arte di costruire la città. L'urbanistica secondo i suoi fondamenti artistici. Milano: Jaca Book, 20 I 6.

Venturi Robert, Scott Brown Denise, Izenour Steven (1977). Learning from Las Vegas: The Forgotten Symbolism of Architectural Form. Cambridge (USA): MIT Press.

Zevi Bruno (1948). Saper vedere l'architettura. Roma: Einaudi (collana Piccola biblioteca Einaudi 2009).

Zevi Bruno, Benincasa Carmine (1986). Comunicare l'architettura. Torino: SEAT.

\section{Authors}

Alfonso Ippolito, Sapienza Università di Roma, alfonso.ippolito@uniromal .it

Martina Attenni, Sapienza Università di Roma, martina.attenni@uniroma l.it

Federica Caporrella, Sapienza Università di Roma, caporrellafederica@gmail.com

To cite this chapter. Ippolito Alfonso, Attenni Martina, Caporrella Federica (2020). ri/segno/ri/segno. In Arena A., Arena M., Brandolino R.G., Colistra D., Ginex G., Mediati D., Nucifora S., Raffa P. (a cura di). Connettere. Un disegno per annodare e tessere. Atti del $42^{\circ}$ Convegno Internazionale dei Docenti delle Discipline della Rappresentazione/Connecting. Drawing for weaving relationships. Proceedings of the 42th International Conference of Representation Disciplines Teachers. Milano: FrancoAngeli, pp. 55।-566. 